\title{
Facebook Birthday Postings from a Language Ecology Perspective in Russian, German, American English, and French
}

\author{
Olga Karamalak \\ National Research University Higher School of Economics
}

\begin{abstract}
Correspondence concerning this article should be addressed to Olga Karamalak, Foreign Languages Department of National Research University Higher School of Economics, 47/7 Bolshaya Ordinka St., Building 2, Room 108, Moscow, Russian Federation, 115184.E-mail: okaramalak@hse.ru
\end{abstract}

\begin{abstract}
The aim of the paper is to examine Facebook postings from an ecological language perspective as a special type of discourse of "everyday life" with an orientating function, to evaluate the environmental potential of this network that influences the character of the posts, and to determine cultural differences in thinking and expressing birthday greetings on the Facebook platform. The paper outlines some specific features of the Facebook environment or niche such as the reduced characters of the message, the use of abbreviations, simple structures, merging and interaction of written and spoken languages, and the use of graphical signs to convey emotions. The methodological approach was to compile a database by randomly gathering, from various Facebook timelines, 680 birthday postings in Russian, American English, German, and French. The posts were then analyzed according to three dimensions: (1) focus of the greetings on the specific day or years to come / life in general (Western vs. non-Western countries, analytical vs. holistic mindsets); (2) use of nominal structures; (3) stress/emphasis on characteristic features of a person, compliments. Various psycholinguistic and cultural aspects of the verbal greetings from the timelines of Russian, American, German, and French users of the social net are singled out in terms of holistic and analytical types of critical thinking. The data collection shows that while Russians and Germans predominantly display holistic thinking, as expressed in birthday postings of a general character and wishes in general for the upcoming year or years to come, Americans and the French display analytical thinking as their birthday posts are more focused on that special day. Most birthday postings are usually short and have one similar pattern. Americans use a lot of praise and stress personal relations. French postings are very emotional often expressing love and kisses. This study shows that analysis of Facebook birthday postings should be multimodal and complex, taking into account a complex interaction of a number of internal and external factors and a personal inclusion into socio-cultural interactions.
\end{abstract}

Keywords: language ecology, Facebook, birthday greetings, posting, holistic thinking, analytical thinking

Cognitive aspects of Internet discourse in the digital media have lately become an important multidisciplinary issue in the development of the contemporary sciences. This paper investigates Facebook posts as a special type of discourse of "everyday life" with an orientating function from the distributed cognition and language perspective (Cowley, 2011), and language ecology in general.

The approach connected with the concept "everyday life" is a relatively new one in the Humanities; however, a serious interest in mundane consciousness appeared much earlier. Heidegger (1996) characterizes "everydayness" or "common sense" (Germ. Altaeglichkeit) as "scattered self", "something average", "dissolving in public", that is something impersonal "Das Mann". The concept "everydayness" has obviously some common ground with the externalist ideas (Noë, 2009). A Facebook post is directed "to the world" and, in fact, becomes "distributed", that is, common, global, for all participants to see, read, and comment on.

Facebook posts can be considered an artificial symbolic niche, that is, a network of material 
structures for social interaction that comprise text messages, video, visual, or audio clips posted by users on their own or others' pages aimed at coordinating actions and triggering some changes. Facebook posts are meaning potentials for discourse development or affordances. They allow or afford communication to develop. Following Gibson's ecological approach to perception, the body of the text is not sensemaking symbols by themselves, but the affordances or opportunities for behavior which are meaningful to an observer: "The affordances of the environment are what it offers the animal, what it provides or furnishes, either for good or ill” (Gibson, 1979, p. 127). Posting should not be regarded as given information to be used, it is not an input-output process, but it is some material inscription which, through interaction with an observer, enables the latter to be informed and develop further interactions. Facebook users, being structurally determined in Maturanian terms, in other words, autopoetic (closed in themselves), strive for distribution as social animals by posting situational statuses to orient "others" to act, attract attention, "share", and "offload" emotional states, thereby creating affordances which may result in actions (verbal or behavioral). It is our natural desire to share space, information, feelings, emotions and other intangible things because we live together with others.

The author of any Facebook status can trigger a change in another person's structure. In this paper, a person who interacts with the posted status is considered as an observer. The written comment on the status is the evidence of the feedback encouraged by the author's post. The change may not be explicitly expressed (for example, a person may be influenced by a status and he/she might reflect on it, but not respond in a written form). However, no change is triggered if the status is unnoticed or is noticed but deemed irrelevant to the observer.

The first objective of this paper is to focus on the establishment of a new ecological paradigm in linguistics, where language is viewed as a multimodal activity that proceeds through the interaction of organism and environment. The Facebook platform as a special Internet environment widens and constraints the users' ways to express themselves. On the one hand, it allows to use visuals, congratulating people interactively both in person and in public. On the other hand, it changes the language of congratulations (Internet birthday greetings vs. paper/card greetings). In this paper, language is regarded as a complex activity which is highly influenced by individuals' physical and social environment. Verbal performance is considered to be a part of distributed human activity.

The second objective of this paper is to outline some specific features of Facebook as an artificial symbolic niche, regarding it as an environment for extended, distributed, and diverse ecology with definite culturally-oriented values, in order to perform a linguo-cultural analysis of Facebook birthday greetings posted by speakers of German, American English, French and Russian in terms of holistic and analytical paradigms of critical thinking.

The methodological approach was to compile a database by randomly gathering, from various Facebook timelines, 680 birthday postings in Russian, American English, German, and French. The posts were then analyzed according to three dimensions: (1) focus of the greetings on the specific day or years to come / life in general (Western vs. non-Western countries, analytical vs. holistic mindsets); (2) use of nominal structures; (3) stress/emphasis on characteristic features of a person, compliments.

The paper is structured in five sections: the first section is an introduction; the second is devoted to the ecological paradigm in linguistics; the third is about the constraints and affordances of Facebook as a niche that influences the writings; the fourth presents a linguo-cultural analysis of birthday postings by speakers of Russian, German, American English and French; lastly, section five draws the conclusion of the paper.

\section{Materials and Methods}

\section{New Paradigm in Linguistics: Language Ecology}

Since the 1970s, twentieth-century linguistics has seen a post-structural (anthropological) paradigm focusing on communicative, cognitive, cultural and other contexts (for example, environmental) of a language system (Kiklevich, 2014, p. 25). This paradigm can be called ecological since, in its broadest definition, 'language ecology' is a science that studies language, organisms, and environmental interactions.

Kravchenko, a Russian linguist, views language ecology in terms of bio- social function of the language - the function to sustain a society as a living system in unity with its cognitive (language orienting) interactions (Kravchenko, 2014). He considers this approach to be helpful in understanding the specific features of onto- and phylogenesis of homo sapiens, that is, the system of value guidelines possessed by a person and a society.

Studies which start from the premise that consciousness is determinedbycausal processes beyond the body and the brain, also known as the theory of "extended cognition", are growing in numbers; see, for example, Cowley (2011); Love (2004); Hodges (2007); Linell (2009); Thibault (2005). According to this neolinguistic approach, which promotes the distributed nature of language and cognition, cognitive processes 
are distributed through our minds, bodies, social and physical dimensions. Stephen Cowley (2011,p. 1) states that, "cognition is cultural and embodied: while much happens in the brain, events arise as people interact both with each other and the world", expressing that the idea of "extended cognition" is the realization of the fact that in everyday communication extended resources expand our cognitive abilities.

Consequently, language is studied as a complex activity holistically and interdisciplinarily. The popularity of holism (fr. Greek holos - "whole") is reasoned by the shift in the scientific paradigm as a result of the exact science and humanitarian integration. Linguistic atomism, when language units are studied separately from the person who produced them and the environment where they were produced, no longer meets the demands of a modern researcher. Nowadays, linguistics merges with other humanitarian and exact sciences and allows a researcher to give a wider picture of this or that language phenomenon. Language is understood as an embodied interactive and ecological activity, a mode of living together.

In different scientific fields there appears the idea of non-reductionist wholeness - the unity of organism (organism biology, theory of peptide bond, etc.), the wholeness of atomic and subatomic world, wholeness of perception (gestalt psychology), interconnection of different societies' elements (autopsies, Næss' "deep ecology", Gaia hypothesis, theory of ecological egalitarianism, internal value, etc.).

(Obolkina, 2005, p. 10)

Moreover,Gibson, a founderofecological psychology in perception, challenged the idea that the nervous system actively constructs conscious visual perception and, instead, promoted the notion of ecological psychology, in which the mind directly perceives environmental stimuli without additional cognitive construction or processing. To Gibson, perception is a compilation of the person's environment and how the person interacts with it. This perspective gave rise to the development of the non-representational approach in radical embodied cognitive science, (nonrepresentational approach) in which perception and cognition are understood only in terms of action in the environment (Chemero, 2009). Antonio Chemero argues that cognition should be described in terms of agent-environment dynamics, rather than in terms of computation and representation.

Today, Cartesian dualism (the juxtaposition of biological to socio- cultural phenomena) is no longer popular in the fundamental sciences or among contemporary linguists. Post-structural, neoCartesian language studies shift the focus to empirical language research connected with the functioning of living systems (Kravchenko, 2004, p. 182).
Alexandrov, a well-known Russian psychologist and neurophysiologist, stresses that the riot against Cartesianism began with Russia, who first witnessed the rebellion against this mechanistic approach that gained widespread acceptance among Western researchers. Furthermore, Alexandrov argues that Russian and Soviet history has deep roots of an anti-reductionist approach (Alexandrov, 2009). As irrefutable evidence of this the author brings the following examples: Bogdanov's Tectology (19131917) appeared much earlier than Bertalanffy's works on the general systems theory, and Anokhin's theory of a functional system by far determined the main cybernetic regularities presented later by Wiener ( $p$. 11).

Pelevin, in his novel The Love for three Zuckerbrins, writes that:

We are all parts of one whole and a human being's main delusion is the belief that there is some "outer" world detached by the air gap surrounding him or her. A human consists of this very world, intergrowing through with thousands of green branches. He or she is an interweave of branches rising from the lake of life. Mirroring in its surface, the branches see their separateness to that extent as a mirroring jack can believe in the separateness, not realizing that he is played in a Russian card game "Durak" and doesn't function without the pack of playing cards. (Pelevin, 2014, pp. 16-17)

The metaphorical statement of this modern writer shows the philosophical understanding of a human as a part of society, that is, distributed in the world. The organism is not separated from the environment: they are not two components of the system but two halves of one wholeness. They interact recursively, meaning that a person behaves or says something (saying is also regarded as behavior in the language environment) in correlation with the environment he or she interacts with, creating it at the same time.

Professor Noë of the University of California at Berkley compares people metaphorically to a plant as opposed to a berry: "We are not like the berry that can be easily plucked, but rather like the plant itself, rooted in the earth and enmeshed in the brambles" (Noë, 2009, p. 69), arguing that a person is not a closed module of an autonomous whole. Developing this idea further, Noë states:

A person is not his or her brain and we are not locked up in a prison of our own ideas and sensations. We are out of our brains. Meaningful thought arises only for the whole animal dynamically engaged with its environment. Consciousness is not something that happens inside us: it is something that we 
do, actively, in our dynamic interaction with

the world around us. (Noë, 2009, p. 79).

In other words, our atmosphere is not separate from others. Our feelings and habits of thinking are part of a complex web that links us all together; it is our "ecology of thought". This ecology is the living network of memory and awareness, one that is not limited to any single person but is in fact held collectively. Out of this ecology comes the collective atmosphere in which we all live and work (Isaacs, 2009).

Haugen considers language ecology as a science about interrelations between language and its environment, whereby by 'environment' he understands the society that speaks the same language. Language in general exists only in the speaker's minds and functions in interactions with other social and natural environments. Language ecology depends on the people who learn, practice, and pass on to others (Haugen, 1972). This is one of the modern branches of linguistics formed by unifying social, psychological, and philosophical branches of linguistics.

\section{Facebook Niche and Birthday Postings as Future- Oriented Actions}

The human's signal system emerges from the interaction of the mind, body, and environmental interactions. The claim that language is biosocial signals a new epistemology based on understanding language as a biological phenomenon and our existence as taking shape in language for social interactions.

Language behavior is a result of distributed activities, that is, the dynamic systems or organisms and the environment. Language action is a physiological ability for social orientation. Compiling the senses of seeing, hearing, and touch, language functions to coordinate these actions into the information symbolic environment (Breskin, 2013). Though people have their own behavioral predispositions and are who they are, it is also undeniable that how an individual performs and acts depend on who he or she interacts with-plunging them into the stream of joint activity. Consequently, language is biological and social; it should be studied as individual action in the semiotic environment in correlated to the environment and to other individuals who are part of the corresponding environment.

This language interpretation corresponds to the understanding of perception as action, which can be traced to the American scholar, Gibson (1962), and to the Soviet scholar Zaporozhets (1967). This perspective is still popular in Russian psychology (Barabanshikov, 2002; Sergienko, 2006) and cognition in general; according to Maturana and Varela, cognition is action and action is cognition, in turn (Maturana \& Varela, 1987). Language-action framework advocates the coordination among people to get things done. Moreover, it supports the development and maintenance of social relationship and culture.

The understanding of action as aimed at a target phenomenon supports the idea that an aim is a central concept in any model behavior (Heisenberg, 1994). The important thing is that any action is mostly determined not by the previous events but by the required future result (Dewey, 1969). "Coherent individual action to adapt to something reflects the world in advance, a person's activity is not a feedback on the past event, but a preparation for the future" (Alexandrov, 2009, p. 103). Thus, Facebook postings are directed to the future, if we consider birthday greetings, it is obvious that they are aimed at the future: to create a positive feeling of being important, cared for, and loved.

Posting birthday greetings on Facebook timelines is a linguistic action aimed at the future with an orienting function. It manifests itself in the influence of congratulations on the people celebrating their birthdays, that is, those people who received the congratulations on that day experience the pleasure or fun of the fact that somebody paid attention to them and greeted them. Pleasure is a basic psychophysiological human need. The aim of psychological activity in general is to avoid displeasure and reach pleasure (Fechner, 1966).

Postings are indexical since they are contextualized by the stream of sensual phenomena. Internet postings are directed to the world, they become distributed, common, and global as a lot of Facebook users can read them. It is important to stress the causal interrelation of a newly created niche or environment (social net) and Facebook users, who act within this environment. As a result, specific symbolic systems are formed with the help of graphical, verbal, and non-verbal means.

Facebook as an environment observed in the article is a particular niche of Internet discourse. Through Maturana's and Varela's lens, we can understand this niche as a domain of interactions:

Living systems are units of interactions; they exist in an ambience. From a purely biological point of view they cannot be understood independently of that part of the ambience with which they interact: the niche; nor can the niche be defined independently of the living system that specifies it". (Maturana \& Varela, 1987, p. 9)

Studying Facebook's verbal signs, we should take into account the factors of e-discourse niche of the social network. Being an observer, a niche is considered as a part of the environment where the participants interact with one another. Birthday greetings on Facebook are studied in correlation with an e-environment and Facebook users. It is important to mention that every social net has its constraints 
and affordances or expansion of opportunities in expressing some information or birthday greeting in particular.

Facebook being very popular in the US and Europe was chosen as a reference point for linguo-cultural research analysis. Russian speaking people mostly use "Vkontakte", though Russian cosmopolitan people are registered on Facebook too. Birthday greetings on the platform "Vkontakte" are mostly presented in the form of audio, video, or graphical ready-made birthday cards. Whereas on Facebook, users mostly write individual, here-and-now greetings (possibly because the options to use ready-made samples are restricted and audio possibilities are scarce). The more options that are allowed, the more these options are used, thus integrating one with another.

Studying the Facebook niche, we came to the conclusion that it allows posts to be of a reductionist nature. Abbreviations and word curtailment in the Internet environment is an overall tendency in order to economize language efforts. In the e-social networks, a special speech genre has been formed which is characterized by shortenings, abbreviations, and the use of brief texts (Marchenko, 2015). This can be traced in birthday greetings as well, for example: in American English, OMG (Oh My God), Happy B day (Happy Birthday), Happy birthday cuz (Happy birthday cousin), HB (Happy Birthday), HBD (Happy Birthday); in Russian, С днюхой (С днем рождения), др (день рождения); in French, Joyeux anniv (Joyeux anniversaire), bon annive (bon anniversaire), bonne annif (bon anniversaire).

It should be noted that German birthday greetings mostly lack abbreviations, which can perhaps be explained by the cultural values attached to such truncations: shortening a word might be regarded as a lack of respect, whereas in other cultures it is fairly accepted. In greetings posted by Russians there are some reductions but they are used rarely ( $2 \%$ in the analyzed e-greetings).

The reductionist character is witnessed in the short nominal form of a birthday greeting such as: "С Днем Рождения", "Нарpy Birthday", "Bon anniversaire”, "Alles Gutte". This is explained by a fast city pulse and hectic lifestyle that results in lack of time, a lot of "friends", "friends of friends", etc. on Facebook most of which are just acquaintances who rarely meet or even interact.

Facebook environment prompts birthday posts to be simple, everyday-like, and arguably hackneyed. Cognitive effort and the strive for creativity are witnessed only when a birthday person is really important, valued, and appreciated by the greeter. Having hundreds and thousands of friends, it becomes impossible to write creative wishes on a daily basis.

The merging and interaction of spoken/colloquial and written speech results in the emergence of spontaneous written speech which mimics the dynamics of a spoken exchange on different levels: graphical, lexical, grammatical, etc. Marchenko states that there is a tendency to transfer the sound of spoken speech by changing the spelling and forming a new 'speech-like' written text (Marchenko, 2013). Furthermore, electronic writing, though less emotional than speech, is acquiring more emotionality with the use of icons. To compensate for timber and accentuate parts of written speech, people also use the CAPSLOCK, a lot of exclamation marks, and letter repetitions: HHAAPPPPYY BBIIRRTTHHDDAAYY, AAMMAANNDDAA!!!! Have a BLESSED DAY!!! !/C Днём Рождения!!!!!!!!!!!!!!!!!!!!!!!!!!!!!!!!!!!!!!

Whether an Internet-environment or a new virtual indexical niche - Facebook has become a part of mundane consciousness. Facebook is treated as a novel virtual indexical niche of everyday life with the orientating function. A person who makes a post influences or orients the cognitive domain of an observer. Any e-post presents a potential for e-discourse development or affordances, i.e. it affords the development of communication. Birthday greetings are personal expressions, in most cases they are not cut- \&-paste greeting clichés, although they may seem like clichés because of their repetition; however, they are personal cultural short inscriptions. Most of them, as mentioned above, are standard phrases but some are creative, full of compliments or refer to some events experienced with a birthday person. The Facebook social network is used as an environment for extended language ecology with definite system of values.

\section{Results and Discussion}

\section{Linguo-Cultural Analysis of Birthday Postings in Russian, German, American English, and French Languages}

The section aims to analyze the specific features of birthday greeting postings by Russian, American English, German, and French Facebook users and study verbal behavior on Facebook to determine the information about the specific features of these people's ways of thinking (from personality to society). Verbal behavior in the social net is regarded as a process or an action aimed at the change in psycho-physiological state of the recipient. Based on the verbal birthday postings, we believe that it is possible to single out some specific features of cultural mentality event perception of this holiday related to the psychological phenomenon of a person as a representative of a separate sociocultural sphere.

According to Alexandrov, learning activity and 
forming an individual experience is culturally and genetically determined. People do not only speak different languages but think differently to reach one result: different brain activity has been registered and even different brain morphology (Alexandrov, 2013). Considering this, it is evident that the Facebook niche of language interactions is culturally dependent. People of different cultures interact and behave differently on the same social platform.

Luria, Vygotsky, and their followers speak about the cultural influence on the particular formation of a subjective experience that is currently well known. Cultural factors influence perception, cognition, and other psychological processes, including particularly language. In Alexandrov's work, People, Cultures, Genes, he argues for the co-evolution of genes and culture:

Extended theory of evolution includes environment or ecological heritability along with genetic one. A human creates a special environment and gene pool is influenced not only by physical environment but also by the environment created by that genome. A niche influences the selection of corresponding pools, the latter construct and reconstruct the niche, and this reconstructed niche favors the corresponding pools. (Alexandrov, 2014, p. 25)

The cultural aspect, along with the physical environment of Facebook, determines language activity in this social network. Any human activity is determined, dependent, and formed in the culture. The same social phenomena are perceived and interpreted differently by different cultural formations.

AccordingtotheSapir-Whorfhypothesis oflinguistic relativity, cognitive processes, such as thought and experience, may be influenced by the categories and patterns of the language a person speaks. Thus, language affects its speakers' worldview or cognition. Consequently, mental representations can be changed under the influence of language and cultural systems (Whorf, 1956). The mentality of different people influences their perception, categorization, and conceptualization of the same things and phenomena. Popova and Sternin consider that "national mentality is a national way of perception and understanding of the reality determined by the aggregate cognitive stereotypes of the nation" (Popova \& Sternin, 2007, p. 59). Everything is culturally dependent and different languages generate different ways of seeing the world thus determining one's worldview.

Karasik says "language is one of the keys to the culture of society and the inner world of the person" (Karasik, 2009, p. 5). He further emphasizes that "a human's behavior is determined by the cultural values, situational circumstances and individual experience. Therefore, communicative behavior and knowledge of the world can be explained by the triad - culture, situation, individual cognition" (Karasik, 2009, p. 6). Culturally determined Facebook users post different birthday greetings depending on the culture that they belong to, though performing one and the same act offering congratulations.

Our case study, focused on Facebook birthday greeting posts by Russian, American, German, and French-speaking people, demonstrates the difference in the manner of congratulation. This paper is not intended to study the genre of greetings in detail. However, it is worth noting that this genre presents a prototypical model or a framework in the consciousness of a speaker, a set of speech rules and samples. These language and semiotic models are formed in a specific cultural environment and are passed on from one generation to another; they also give an idea how people think and behave in different cultures.

Dudkina compares the greeting genre in American and Russian cultures (Dudkina, 2011) and comes to the conclusion that Russian greetings are mostly performed on general or group occasions (New Year, Christmas, March 8, etc.) while American greetings are mostly on personal occasions (a new job, a graduation, etc.). However, any greeting is directed to a person and is conveyed on a particular occasion. In different cultures there can exist different occasions for congratulations because occasions and holidays are different and, even if they are the same, they can be perceived differently. For example, New Year in Russia is much more festive and important than in Europe and America where Christmas comes first and outshines New Year. Birthdays are celebrated in all the countries, but in Russia and Germany it is bad luck to congratulate a person in advance or celebrate it.

Texting on Facebook is value-oriented insofar as it touches upon everyday life and practices, is reflected in behavior patterns, and results in the choice of determinate actions (Hofstede, 2010). The choice of actions also includes the choice of verbal patterns. People from different cultures offer congratulations on birthdays in different ways as illustrated through the examined posts on Facebook timelines depending on their belonging to "Western" or "non-Western" cultures with the predominance of analytical and holistic thinking correspondingly. The division of cultures into "Western" and "Eastern" is conditioned not only by the territorial position, but also and mainly by the type of cognition. Nisbett et al. (2001) comparing the specifics of cognitive processes in different cultures came to the conclusion that Eastern countries use formal logics rarely and perceive the world as a continuity while Western countries have analytical thinking and focus on discrete and detached objects.

Following Alexandrov (2009) Russian way of 
thinking belongs to the eastern cultures. Russian speakers on Facebook generally use abstract, general notions such as health, love, happiness, wealth, and prosperity, when the post birthday greetings:

Анюта, с днем рождения!!!! Безграничного веселья тебе, успехов и любви!!!! Очень скучаю! (Anjuta ${ }^{1}$, happy birthday!!! Endless happiness, luck and love!!! I miss you a lot!) Леночка, С Днем Рождения!! Желаю тебе счастья!! (Lenochka ${ }^{1}$, Happy Birthday! Wish you happiness!!)

Аня, поздравляю с Днем рождения!!! Улыбок, счастья, успехов, здоровья и хорошего настроения! (Anya, happy Birthday!!! Smiles, happiness, luck, health and good mood!)

Анечка, поздравляю с Днем Рождения! Всего самого прекрасного, успешного и позитивного в новом году!!! (Anechka ${ }^{1}$ congratulate you on your birthday! Wish you the most wonderful, successful and positive next year!!!

С Днем рождения, Олечка! В этот прекрасный весенний день поздравляю тебя и желаю всегда положительных и ярких эмоций! Здоровья крепкого! Успехов во всех благих делах! Пусть каждый день будет наполнен любовью и теплом родных и близких! (Нарру Birthday Olechka ${ }^{1}$ ! On this wonderful spring day I congratulate you and wish you positive and bright emotions! Strong health! Success in everything! May every day be filled with love and warmth of your close people's hearts!)

Дорогая Анна!

Как говориться Поздно Чем Никогда, С Днем Рождения!

Желаю тебе Здоровья, Счастья, Большой Любви, Верных Друзей и Удачи во Всем!

С днем рождения! Любви, успехов, приятных сюрпризов, позитива без грании, увлекательных путешествий! (Dear Anna! They say Better Late Than Never, Happy Birthday! Wish you Health, Happiness, Big Love, True Friends and Luck in Everything!)

The abstract, general values are interconnected (happiness presupposes health, love, and visa versa). This is the evidence of holistic way of thinking (perceiving the world as a whole) that is characteristic of Russian culture.

Holism is also witnessed in the Russian birthday greetings because they wish some positive things for the coming year or many years to come, normally a particular birth day is hardly ever mentioned. In the example below, the author of the greeting even stresses "not only today".

С днем рождения, начальник! Всего самого

\footnotetext{
${ }^{1}$ Endearing use of the name
}

доброго и желательно не только сегодня! (Happy Birthday, boss! The best and kindest things and preferably not only today!)

Russian speakers greet their friends on Facebook in English traditionally wishing abstract and general notions. These greetings stand out from the others posted in English (see Fig. 1 below).

Happy Birthday, dearest!! Wish you all the best I

can only think of)))

Happy Birthday! Luck, love, lots of laughter!!Happy Birthday! Luck, love, lots of laughter!!

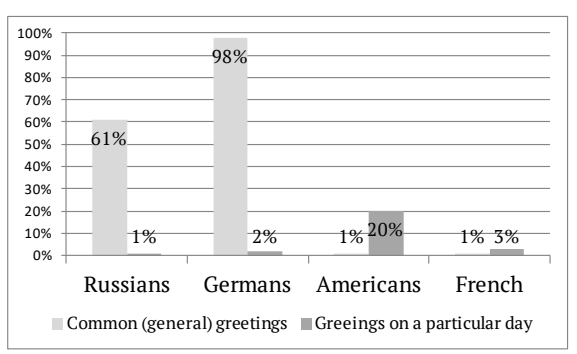

Figure 1. Common (general) birthday greetings vs greetings on a particular day.

It should be noted that if a person is very important, loved, and appreciated, and the addresser knows about the wishes, hobbies, preferences or the upcoming event in future, then the desired valuable things become concrete or specific, for example: people wish excellent vacation or rest on the sea, pass the exams successfully, find a true love, etc.

Greetings in the Russian language are generally long and various in content; the deserted nominal form "С днем рождения" ("Happy Birthday”) is rarely used. People normally express their wishes as great values and important greetings: in Russian culture it is not typical to simply write "happy birthday" since this can be perceived as expressing an indifferent attitude to a person (see Fig 2 below).

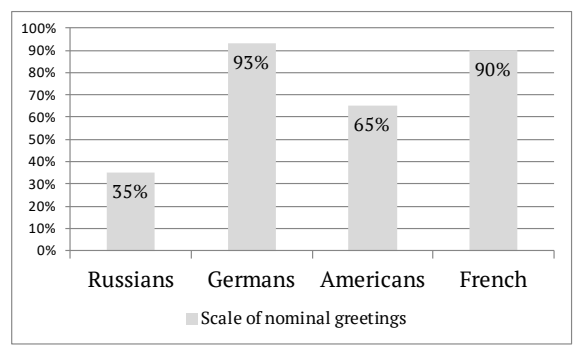

Figure 2. Nominal birthday greetings.

The The focus on personal relations, praise and individual features of a birthday person are illustrated in the following examples:

- "ты очень хороший человек" (you are a very nice person),

- “мне не хватает “культурной странички”" (I miss you "my cultural page of the book"),

- "Хочу, чтобы вы оставались таким же добрым и приветливым Человечком!" (Wish you to stay 
a kind hearted and friendly Person!),

- “Красотка!" (The beauty),

- "Вы замечательный руководитель" (You are a wonderful boss),

- “ты умница" (Clever girl!),

- “красавица-русалочка" (a beautiful mermaid),

- “оставайся всегда такой же молодой” (stay as young as you are);

- “скучаю” (miss you),

- “мне очень приятно, что именно вы преподаете у нас" (I enjoy your teaching very much),

- “мы вас любим" (we love you)

- Анюта, с днем рождения!!!! Безграничного веселья тебе, успехов и любви!!!! Очень скучаю! (Anjuta ${ }^{2}$, happy birthday!!! Endless happiness, luck and love!!! Miss you very much!)

- Анечка! С днем рождения! недавно вспоминала, как же мне не хватает «культурной странички»): (Anechka! Happy Birthday! I've recently remembered you and how much I miss "my cultural page of the book")

- Я желаю вам счастья, здоровья, послушных учеников! мне очень приятно, что именно вы преподаете у нас и дополнительно с нами со всеми занимаетесь! Я рада, что это вы! Хочу, чтобы вы оставались таким-же добрым и приветливым Человечком! Мы вас очень любим!! (I wish you happiness, health, good students! I enjoy your teaching very much and your extra work with us! I am happy that we have you! Wish you to stay a kind hearted and friendly Person! We love you a lot!)

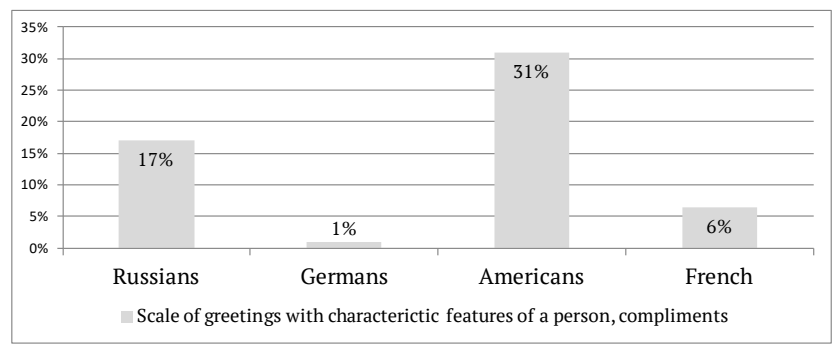

Figure 3. Birthday greetings with characteristic features of a person, compliments.

It is interesting that German-speaking Facebook users also usually wish abstract positive things (see Fig. 1 above). They usually post "Alles Gute, alles Liebe zum Geburtstag” (All the best and love, happy birthday). Normally they do not focus on the particular day; however, there are a few examples when they do:

- Alles gute zum Geburstsg. Feier mal schön (All the best. Happy birthday! Have a good party),

- Alles Liebe zum Geburtstag! Genieß Deinen Tag....und Du hast heute sogar ne Extraportion Sonnenschein dazu bekommen! smile emoticon (All

\footnotetext{
${ }^{2}$ Endearing use of the name

${ }^{3}$ Endearing use of the name
}

the best, Happy birthday! Enjoy your day and get extra sunshine for you!).

As was previously mentioned, most of the greetings are general:

- Hallo Olaf, alles GUTE zum Geburtstag! (Hello Olaf, all the BEST, happy birthday),

- Herzlichen Glückwunsch und alles Gute ......(Wish of happiness from the heart and all the best),

- Alles Gute zum Geburtstag!!! (all the best, happy birthday).

Most greetings even lack “Zum Geburtstag”, instead people use "Alles Gute", "Alles Liebe". These forms function simultaneously in the nominative function as happy birthday and in the "wish" function, that is, they are used to wish general good things (see Fig. 2 above). Out of 201 greetings analyzed, only 33 had the wordings "Zum Geburtstag".

- Alles Gute! :) (All the best)

- alles liebe :) (All the love)

- ois guade! (All the best)

- Hallo Julia, ich wünsche Dir alles alles Gute und Liebe zum Geburtstag!! Feier schön und lass es Dir gut gehen!! :-) (Hello Julia, I wish you all the best, happy birthday!! Have a good party and let everything be good).

- Alles alles Liebe zum Geburtstag, Julia:) Feier schön! (All the best, happy birthday, Julia. Have a good party!)

- Heymaus! Alles alles liebe und gute zum Geburtstag! Bleib so ne liebe Schnecke und va gesund! :- $($ Hey mouse ${ }^{4}$. All the best and all the love, happy birthday! Stay a lovely snail ${ }^{4}$ and much health to you! :-*).

The last example shows a personalized post that calls up personal features of the birthday person along with a positive evaluation and a wish for good health.

Given that Germany is undoubtedly a Western country a question appears: why do we witness a holistic type of thinking characteristic for most Eastern countries? Surprisingly but Germany is an example of a holistic type of thinking (Toomela, 2007; Ash, 1998; Harrington, 1995). It explains the appearance of such works by Leibnitz, Hegel, Shelling and others devoted to a holistic approach to science. Gestalt psychology (we view things as organized, structural wholes) appeared in Germany and is also regarded as the proof of holistic thinking (Alexandrov, 2013). Holistic approach is about the unity of cooperative and integrative objects and phenomena. "Western" and "non-Western" cognition should not be understood as a simple dichotomy. Foard and Kemler (1984) introduce analytical-holistic modus or continuum to confirm that some countries are not purely analytical or holistic but mixed or transitional. The following countries can be placed from analytic to holistic on a continuum: The USA - Western Europe -

\footnotetext{
$\overline{{ }^{4} \text { Endearing type of address (zoonisms) }}$
} 
Eastern and Central Europe (including Russia) - South East Asia (Varnum et al., 2008).

Revisiting the above-mentioned German birthday greetings and analyzing them in terms of how they express praise and personal relations with a birthday person, we found that most of the greetings are of a nominative character, the greeting itself is of great value (see Figure 3 above). By contrast, in American and French cultures the greetings are aimed at the particular day of birth and the wishes are directed to that special day (see Figure 1 above).

- Joyeux anniversaire et belle journée ! Bises (Happy Birthday and wish you a beautiful day! Kisses)

- Joyeux anniversaire. toute belle journée. (Happy Birthday and wish you a beautiful day.)

- Joyeux anniversaire et très belle journée ! Bisous (Happy Birthday and wish you a beautiful day! Kisses)

- Happy Birthday Amanda. Hope your day is great!!

- Happy Birthday. Have an awesome day.

- Happy birthday Amanda have a great day!

- Happy birthday to this sweet, beautiful lady and best friend! I hope you have the most fabulous day ever!! Love you darling!

This focus on the special day, in our opinion, can be explained by the analytical (Western) or taxonomic type of thinking, since the USA and Western Europe belong to "Western" cultures (Henrich et al., 2010; Grossmann \& Varnum, 2011). Moreover, it is characteristic of the birthday language structure "Happy Birthday" and "Joyeux Anniversaire" where "day" or "anniversaire" are used in accusative, without preposition in comparison with dative in Russian and German "С Днем Рождения” (literary "with day of birthday") and "Zum Geburtstag" (literary "with birth day") correspondingly. The experiments were conducted by Buchtel\&Norenzayan (2009) and proved that people who belong to "Western cultures" choose logic and rational types of decision making unlike people of "Eastern culture" led mostly by intuition. Henrich et al. (2010) conclude that a mature individual uses both cognitive systems (rationalism and intuition); however, a given culture uses more often one system at the expense of another when faced with some kind of decision-making problem. Holistics cultures are connected with collectivism while analytic cultures with individualism (Varnum et al., 2008; Uskul et al., 2008).

American birthday greetings are rich for praise and feelings, most are emotional and are about personal relations with a birthday person (see Figure 3 above).

- I want to wish the happiest of birthdays to Amanda Stewart - you are the best girlfriend in the world and I couldnıt be happier to be by your side. Love you!

- Happy Birthday to one of the greats at CC. I appreciate ALL you do! Have a great day.

- Happy Birthday Homegirl :)I hope you have a day as amazing as you are!!

- Happy birthday to one of my favorite people!!!!!!!!!! I hope you have a wonderful birthday!

- Happy birthday to you my amazingly talented friend. Hope you have an awesome day.

- Happy birthday to this sweet, beautiful lady and best friend! I hope you have the most fabulous day ever!! Love you darling!

French Facebook birthday greetings are very emotional and express love, which can be observed through the abundant use of emoticons (smiles, hearts, kisses) and a great number of exclamation mark. The word "kiss" ("bisous", "bises", "bosou", "bisous") is written very often; however, the spelling of this word is less important than the emotional state. In the following examples kisses are addressed not only to a birthday person but also to his family:

- Bj Vincent, avec un peu d'avance je te souhaite un excellent anniversaire bisous a vous trois (Hello Vincent, a little bit in adavance I wish you an excellent birthday, kisses to three of you)

- $\quad$ Bisous a toute la famille (Kisses to all the family)

The use of reference such as "mon Rico adore" (my adorable Rico), "mon Henrico d'amour" (my beloved Henrico) shows us the desire to express special attitude to a birthday person. However, in comparison to American birthday greetings, the French greetings do not have as much praise and focus on personal relashions (see Figure 3 above).

\section{Conclusion}

To sum up, our study signals the usefulness of a new ecological paradigm in linguistics, wherein language is viewed as action aimed at achieving future results (to make someone happy showing the significance of a person) and proceeds through the interaction of organism and environment. Language is regarded as a complex activity (holistic approach) where verbal performance is considered to be a part of distributed human activity, coordination between the dynamic system or organism and environment.

In conclusion Facebook birthday postings are considered as an artificial symbolic niche, in other words, a network of material structures for social interaction that comprises text messages, video, visual, or sound images put by users on their own or others' pages aimed at coordinating actions and triggering changes. Some of the features include the reduced character of the message, the use of abbreviations, simple structures, merging and interaction of written and spoken languages, and the use of graphical signs to convey emotions. The Facebook social network is used as an environment for extended, distributed, 
and diverse ecology with definite culturally-oriented values. Verbal performance is considered to be a part of distributed human activity, coordination between the dynamic system or organism and environment.

Facebook birthday postings are a language action aimed at the future and have an orienting function (to influence and orient others, making a change in others, that is, to give a feeling of pleasure to a birthday person. Birthday greetings on Facebook are verbal actions in the niche of a virtual e-discourse and a part of everyday reality. They are culturally and environmentally dependent and determined. People of different cultures have different values, different manners of behavior in the Internet environment, and roughly fall into the division of holistic and analytical types of thinking. Russians and Germans predominantly have holistic thinking as it was stated by the scientists above and this is expressed in birthday postings of general character and wishes in general for upcoming year or years to come. Americans and the French have analytical thinking and their birthday posts are focused on that special day (they single it out). Most birthday postings are usually short and have one similar pattern. Americans use a lot of praise and stress personal relations. French postings are very emotional often expressing love and kisses.

Cross-cultural analysis of birthday posts is first introduced as an object of study. The research has its special significance because modern ecological and bio-socio approach in language science is applied empirically. Linguistic forms of birthday greetings recursively influence the perception of this event (a psycholinguistic phenomenon). This comparative work contributes to linguo-cultural research concerning the differences in perception and action (verbal birthday greetings).

Besides birthday events, other aspects of everyday life could be studied using material from Facebook. Research on e-discourse and the phenomenon of everyday life is an expanding sub-field in modern linguistics. Further study is needed on the emergence of e-discourse from personal posts in social networks and the development of communication as joint action. It could be fruitful to analyze the cultural and valuerealizing peculiarities, the constraints of posts, as well as the psychological reasons for posting comments on FB. Spoken-like text types mediated by the Internet are becoming of great interest for linguists because it is a part and parcel of our everyday life.

\section{References}

Alexandrov, Ju. I. (1999). Teorija funkcional'nyh sistem i sistemnaja psihofiziologija [Theory of functional systems and systematic psychophysiology]. In K. V. Sudakov (Ed.), Sistemnye aspekty psihicheskoj dejatel'nosti (pp. 98-152). Moscow, Russia: Editorial URSS.

Alexandrov, Ju. I. (2013, March 1). Mozg i kul'tura [Brain and culture]. Telekanal kul'tura Rossia. Available at http://www.youtube.com/watch?v=-RRfSjobp2s

Alexandrov, Ju. I. (2014). Mozg, subjektivnye miry, kul'tury: Teorii i fakty [Brain, subjective worlds, cultures: Theory and fact]. In Shestaja mezhdunarodnaja konferencija po kognitivnoj nauke: Tezisy dokladov (p. 25). Kaliningrad, Russia: BFU.

Alexandrov, Ju. I., Alexandrova, N. L. (2009). Subyektivnyj opyt, kul'tura i social'nye predstavlenija [Subjective experience, culture and social ideas]. Moscow, Russia: Institut psihologii RAN Publ.

Ash, M. G. (1998). Gestalt psychology in German culture. Holism and the quest for objectivity. Cambridge, UK: Cambridge University Press.

Barabanshhikov, V. A. (2002). Vosprijatie i sobytie [Perception and event]. Saint Petersburg, Russia: Aletejja.

Bereskin, V. Ju. (2013). Homo igneous: Fenomen jazyka dlja kurjashhih i nekurjashhih [Homo igneous: Language phenomenon for smokers and non-smokers]. Filosofskie issledovanija, 12, 228-247. Retrieved from http://e-notabene.ru/fr/ article_10258.html

Chemero, A. (2009). Radical embodied cognitive science. Cambridge, MA: The MIT Press.

Cowley, S. J. (2011). Distributed language. Amsterdam, Netherlands: John Benjamins Publishing Company.

Dewey, J. (1969). The early works. London, UK: Southern Illinois Univ. Press.

Dudkina, N. V. (2011). Rechevoj zhanr pozdravlenija v russkoj i amerikanskoj lingvokul'turah [Language greeting genre in Russian and American liguocultures]. In E. A. Pokrovskaya, N. V. Dudkina \& E. V. Kudinova (Eds.), Rechevye zhanry $v$ dialoge kul'tur (pp. 35-79). Rostov-on-Don, Russia: Foundation.

Fechner, G. T. (1966). Elemente der psychophisik [Elements of psycholinguistics]. New York, NY: Holt, Rinehartand, Winston.

Foard, Ch., \& Kemler, N. D. (1984). Holistic and analytic modes of processing: The multiple determinants of perceptual analysis. Journal of Experimental Psychology: Learning, Memory and Cognition, 113, 94-111.

Gibson, J. (1962). Observations on active touch. Psychological Review, 69, 477-490.

Gibson, J. (1979). The ecological approach to visual perception. Boston, MA: Houghton-Miffin.

Grossmann, I., \& Varnum, M. (2011). Social class, culture, and cognition. Social Psychological and Personality Science, 2, 81-89.

Harrington, A. (1995). Reenchanted science. Holism in German culture from Wilhelm II to Hitler. Princeton, NJ: Princeton University Press.

Haugen, E. (1972). The ecology of language: Essays by 
Einar Haugen. Stanford, CA: Stanford University Press.

Heidegger, M. (1996). Being and time. Albany, NY: State University of New York Press.

Heisenberg, M. (1994). Voluntariness and the general organization of behavior. In R. J. Greenspan \& C. P. Kyriacou (Eds.), Flexibility and constraint in behavioral systems (pp. 147-156). New York, NY: John Wiley \& Sons Ltd.

Henrich, J., Heine, S. J., \& Norenzayan, A. (2010). The weirdest people in the world. Behavioral and Brain Sciences, 33, 61-135.

Hodges, B. H. (2007). Values define fields: The intentional dynamics of driving, carrying, leading, negotiating, and conversing. Ecological Psychology, 19(2), 153-178.

Hofstede, G. J., Hofstede, G., \& Minkov, M. (2010). Cultures and organizations, software of the mind: Intercultural cooperation and its importance for survival (3rd ed.). New York, NY: McGraw-Hill Professional.

Karasik, V. I. (2009). Jazykovye kljuchi [Language keys]. Moscow, Russia: Gnosis.

Kiklevich, A. K. (2014). Dinamicheskaja lingvistika: Mezhdu kodom i diskursom [Dynamic linguistics: Between code and discourse]. Kharkov, Ukraine: Gumanitarnyj centr Publ.

Kravchenko, A. V. (2004). Biosemiotika: Na puti k obyedinennoj nauke [Biosemiotics: On the way to integral science]. Vestnik MGLU. Serija Lingvistika: Problemy Sootnoshenija Kul'tury, Jazyka i Myshlenija $v$ Paradigme Sovremennoj Anglijskoj Leksikologii, 489, 182-194.

Kravchenko, A. V. (2014). Dva vzgljada na jekologiju jazyka i jekologicheskuju lingvistiku [Two approaches on language ecology and ecological linguistics]. Jekologija Jazyka i Kommunikativnaja Praktika, 2, 90-99.

Linell, P. (2009). Rethinking language, mind, and world dialogically: Interactional and contextual theories of human sense-making. Charlotte, NC: Information Age Publishing, Inc.

Love, N. (2004). Cognition and the language myth. Language Sciences, 26(6), 525-544.

Marchenko, N. G. (2013). Social'naja set' "VKontakte": Lingvopragmaticheskij aspekt [Social network "VKontakte": Linguistic and pragmatic aspect] (Unpublished cand. philol. nauk dissertation). Southern Federal University, Rostov-onDon, Russia. Retrieved from http://netess. ru/3jazykoznanie/32175-1-socialnaya-setvkontakte-lingvopragmaticheskiy-aspekt.php

Maturana, H. (1978). Biology of language: The epistemology of reality. In G. Miller \& E. Lenneberg (Eds.), Psychology and biology of language and thought (pp. 28-62). New York, NY: Academic Press. Maturana, U. R., Varela, F. (1987). The tree of knowledge: The biological roots of human understanding. Boston, MA: Shambhala Publications, Inc.

Nisbett, R. E., Peng, K., Choi, I., \& Norenzayan, A. (2001). Culture and systems of thought. Holistic versus analytic cognition. Psychological Review, 108, 291-310.

Noë, A. (2009). Out of our heads: Why you are not your brain, and other lessons from the biology of consciousness. New York, NY: Hill and Wang.

Obolkina, S. V. (2005). Ontologicheskaja grammatika holizma kak filosofskaja problema [The ontological grammar of holism as a philosophical problem] (Unpublished cand. philos. nauk dissertation). Ural State University named after A. M. Gorky, Ekaterinburg, Russia. Retrieved from http:// cheloveknauka.com/ontologicheskayagrammatika-holizma-kak-filosofskayaproblema\#ixzz3TtTkaXuJ

Pelevin, V. O. (2014). Ljubov' $k$ trem cukerbrinam [Love for three Zuckerbrins]. Moscow, Russia: Jeksmo.

Popova, Z. D., \& Sternin, I. A. (2007). Kognitivnaja lingvistika [Cognitive linguistics]. Moscow, Russia: ACT, Vostok-Zapad.

Sergienko, E. A. (2006). Rannee kognitivnoe razvitie. Novyj vzgljad [Early cognitive development. New approach]. Moscow, Russia: IP RAN Publ.

Thibault, P. (2014). Events and affordances: Ecosocial time scales and the two orders of language. Cybernetics \& Human Knowing, 21(1-2), 23-36.

Toomela, A. (2007). Culture of science: Strange history of the methodological thinking in psychology. Integrative Psychological and Behavioral Science, 41, 6-20.

Uskul, A. K., Kitayama, S., \& Nisbett, R. E. (2008). Ecocultural basis of cognition: Farmers and fishermen are more holistic than herders. Proceedings of the National Academy of Sciences of the United States of America, 105(25), 8552-8556.

Varnum, M. E., Grossmann, I., Katunar, D., Nisbett, R. E., \& Kitayama, S. (2008). Holisma in a European cultural context: Differences in cognitive style between Central and East Europeans and Westerns. Journal of Cognition and Culture, 8, 321-333.

Whorf, B. L. (1956). Language, thought and reality: Selected writings of Benjamin Lee Whorf. New York, NY: Wiley.

Zaporozhec,A.V.(1967).Vosprijatieidejstvie[Perception and action]. Moscow, USSR: Prosveshhenie Publ. 